\title{
Stability and microbiological quality of rice bran subjected to different heat treatments
}

\author{
Estabilidade e qualidade microbiológica de farelo de arroz submetido a diferentes tratamentos térmicos
}

\author{
Márcia Gonzaga de Castro OLIVEIRA ${ }^{1}$, Priscila Zaczuk BASSINELLO ${ }^{1 \star}$, \\ Valácia Lemes da Silva LOBO$^{1}$, Maria Madalena RINALDI ${ }^{2}$
}

\begin{abstract}
Rice bran is a byproduct commonly used for animal feeding; however its nutritional value and potential application in human diet have attracted market interest. Its preservation for safe use is still a challenge, so the objective of this study was to determine the quality of commercially available rice bran samples subjected to different heat treatments (extruding, parboiling, toasting, and microwave oven heating) in order to promote stabilization during storage under room temperature. Rice bran samples were collected from two industries, and each treatment was divided in three parts, each corresponding to three repetitions. All samples were evaluated for moisture content, total microorganisms, mold and yeast counting, hydrolytic rancidity, and lipase activity during 90 days of storage. Most of the heat treatments, including domestic and thermoplastic extrusion, generated products which may be used for human consumption under the tested conditions in terms of physicochemical and microbiological quality. The domestic treatments were more efficient in eliminating microorganisms or keeping them within acceptable limits. The toasted rice bran showed satisfactory results in terms of moisture, hydrolytic rancidity control, and lipase activity. Keywords: rancidity; microbial contamination; lipase activity.
\end{abstract}

\section{Resumo}

O farelo de arroz é um subproduto comumente utilizado em ração animal, porém seu valor nutricional e potencial de aproveitamento na alimentação humana vem despertando interesse do mercado. A conservação dessa matéria-prima para uso seguro ainda é um desafio, assim, o objetivo deste trabalho foi avaliar a qualidade de farelos de arroz comercialmente disponíveis, submetidos a diferentes tratamentos térmicos (extrusão, parboilização, torração em fogão e forno micro-ondas) visando à estabilização durante armazenamento em condições ambientais. As amostras foram coletadas em diferentes indústrias e cada tratamento foi dividido em três porções correspondentes a três repetições. Todas as amostras foram avaliadas quanto à umidade, contagem total de microrganismos, rancidez hidrolítica e atividade de lipase, durante 90 dias de armazenamento. A maioria dos tratamentos térmicos, incluindo processo doméstico e extrusão termoplástica, gerou produtos com potencial para consumo humano nas condições testadas, em termos de qualidade físico-química e microbiológica. Os tratamentos domésticos foram mais eficientes para eliminar os microrganismos presentes ou para mantê-los dentro dos limites aceitáveis. O farelo de arroz tratado em fogão apresentou resultados satisfatórios em termos de umidade, controle da rancidez hidrolítica e da atividade lipásica.

Palavras-chave: rancidez; contaminação; atividade lipásica.

\section{Introduction}

Rice bran accounts for 8 to $10 \%$ of the whole grain (BASSINELLO, 2004; CONTE, 2000; ABOISSA..., 2012), and its total production was approximately one million tons in the 2010/2011 Brazilian harvest.

The chemical composition of the rice bran depends on certain factors associated with the grain chemical composition or with milling processes. Rice bran has a significant amount of proteins, lipids, edible fiber, minerals (magnesium, potassium, phosphorus, iron, manganese, and zinc), and vitamins (thiamin, riboflavin, niacin, pyridoxine, pantoteic acid, biotin, and tocopherol) (CARVALHO; BASSINELLO, 2006; HOFFPAUER, 2005; LUH; BARBER; BARBER, 1991; SAUNDERS, 1990; LLOYD; SIEBENMORGEN; BEERS, 2000).
Due to its nutritional value, low cost (DOUAUD, 2007), and potential use in human nutrition, many studies have been conducted to evaluate its use in food. Stabilized bran has a shelf life of approximately six months at temperatures below $30^{\circ} \mathrm{C}$. It has been used abroad in breakfast cereals and in granola tablets, snacks, and extruded food and also as a binder to replace isolated soy protein in food containing chicken meat (CROWLEY; HALLIDAY, 2008), as a supplement for bakery products in functional diets since it is similar to high fiber bread (ABDUL-HAMID; LUAN, 2000), and in soft drinks and as supplementary component in the food industry (KAHLON, 2009). In Brazil, in addition to the animal feed application, rice bran has been used in a "multi-mixture" toasted flour (generally homemade), as part of a Brazilian social program of recovery of malnourished children (SILVA; SANCHES; AMANTE, 2006).

\footnotetext{
Received 27/1/2011

Accepted 27/6/2012 (005249)

Laboratório de Grãos e Subprodutos, Embrapa Arroz e Feijão, Rod. GO-462, Km 12, Zona Rural, CP 179, CEP 75375-000, Santo Antônio de Goiás, GO, Brazil,

e-mail:priscilazb@cnpaf.embrapa.br

${ }^{2}$ Embrapa Cerrados, Rod. Brasília/Fortaleza, BR-020, Km 18, CP 08223, CEP 73310-970, Planaltina, DF, Brazil

${ }^{*}$ Corresponding author
}

DOI: http://dx.doi.org/10.1590/S0101-20612012005000095 
However, the crude bran has not been regularly used in human food in Brazil due to its fast deterioration (CARVALHO, 1995) or to its low stability since during storage there is an intense enzymatic activity of lipase, lipoxygenase, and peroxidase generating bran oil oxidation with considerable increase in acidity and causing odor and rancid flavor (GLUSHENKOVA et al., 1998), factors that limit its use (ABOISSA..., 2012).

Sanitary and hygienic bran conditions during harvesting together with hull residues and starch contamination during dehulling and polishing processes limit its direct use as food (NOGARA, 1994) because these residues may carry a high population of microorganisms, such as fungi, whose spores are resistant to heat and are also able to produce lipases and mycotoxins. Storage conditions may favor insects, fungi, and bacteria growth depreciating grain quality, and consequently promoting enzyme activation (HOFFPAUER, 2005; LUH; BARBER; BARBER, 1991). On the other hand, enzymes, microorganisms, and protease natural inhibitors may be thermolabile or unstable to high temperatures (LUH; BARBER; BARBER, 1991; MALEKIAN et al., 2000). It is known that rice bran lipase is activated by low concentration of $\mathrm{Ca}^{2+}$ and inhibited by heavy metals. Its optimum $\mathrm{pH}$ is between 7.5 and 8.0 , and the optimum temperature is about $37^{\circ} \mathrm{C}$. Peroxidase causes oxidative spoilage of bran components (oil, tocopherols) at low moisture levels. Other enzymes, like lipases, whose activity has been suppressed by combining partial thermal inactivation and dehydration, are reactivated when moisture content increases. Other studies have shown that heat resistance of rice bran enzymes depends upon temperature and time of treatment, as well as upon moisture content, the latter being a critical parameter. The higher the moisture content, the lower the heat resistance.

Thermoplastic extrusion, a method traditionally used in the USA to stabilize rice bran, promotes enzyme inactivation and long product shelf life (CARVALHO; BASSINELLO, 2006; RANDALL et al., 1985). Marsaioli Junior and Rocha (2006) developed and patented a process to stabilize hulled grains and bran using microwave. Rice parboiling is a hydrothermal process that involves the use of high temperature and pressure, and it results in less endosperm contamination of the bran since the parboiled grains become more compact and more resistant to cracks or abrasion. It can be more stable because the parboiling process inactivates the enzymes responsible for lipid degradation (SAUNDERS, 1990; SLAVIN; LAMPE, 1992; SILVA; SANCHES; AMANTE, 2006), but it is not so efficient to eliminate risk of pesticide or mycotoxins contamination (DORS et al., 2011; DORS; BIERHALS; BADIALE-FURLONG, 2011).

There are very few studies regarding microbial and enzymatic stabilization of stored rice bran; therefore, the objective of this study was to assess microbiological quality, lipase activity profile, and hydrolytic rancidity of stored and marketable rice bran that is industrially processed or domestically treated using various heat processes.

\section{Materials and methods}

\subsection{Sample preparation}

Commercially available rice bran samples were used in order to check their quality conditions and microbiological suitability for direct human consumption.

Rice bran used in this study was collected only once from lowland rice cultivars processed by two traditional Brazilian rice processing industries: 1. Agroindustrial Urbano Ltda (Urbano Agroindustrial Ltda), located at Sinop - MT; and 2. Irgovel - Indústria Riograndense de Óleos Vegetais Ltda (Vegetable Oil Industry of Rio Grande do Sul Ltda), located at Pelotas - RS. The sample treatment steps are detailed in Figure 1.

The first industry produces three kinds of rice bran after rice milling, parboiling, or heating processes: crude or whole bran (control); parboiled whole bran, and extruded whole bran (by thermoplastic extrusion), which are considered the test samples ( $4 \mathrm{~kg}$ of the control rice bran and $2 \mathrm{~kg}$ of each one of the others) of the present study.

The second industry uses the collected crude rice bran from the same rice cultivars as the raw material for oil extraction with organic solvent. This process generates the defatted bran, which in turn is submitted to pelletization in order to make it marketable as defatted bran pellets for animal feed. The pellets $(2 \mathrm{~kg})$ were also used as a sample test. Before analyses, this sample was ground using an analytical knife mill (IKA A11 BASIC) to pass through a 32 mesh-sieve $(0.5 \mathrm{~mm})$ to reach a similar granulometry of the other samples.

The industrial samples had no extra treatment at the lab. The crude or whole bran sample (control, non-heat-treated sample) was portioned and each portion was immediately submitted to two different domestic heat processes at the Experimental Kitchen Lab of Embrapa Rice and Beans Research Center, at Santo Antonio de Goiás, GO, as described below. A portion of the control was kept as non-treated sample for comparison reasons.

The first home process was based on the recommendation of Brandão (2009), with adaptations. The rice bran was toasted in a pre-heated $20 \mathrm{~cm}$ diameter Tramontina pan, with $1 / 3$ of its height filled with bran at a temperature of $80^{\circ} \mathrm{C}$ and steering for 6 minutes. The second home process, adapted from Weber (2005), was carried out in a SAMSUNG microwave oven at medium power for six minutes steering the sample every minute underway to standardize the exposure to heat.

After processed, each one of the six samples was well homogenized and divided into three portions, which corresponded to three repetitions of each treatment, respectively. Next, the samples were sent to the Grains and Byproducts Laboratory at Embrapa Rice and Beans Research Center, where they were identified and stored in sterilized polypropylene bags for 90 days at room temperature with monitored relative humidity $(55.64 \%+7.17 \%)$ and temperature $\left(27.35^{\circ} \mathrm{C}+1.14{ }^{\circ} \mathrm{C}\right)$ until analyses. Table 1 shows the codes used for the different samples. 


\subsection{Chemical analyses}

The moisture content of the samples was determined in oven at $105^{\circ} \mathrm{C}$ for 16 hours, according to the official gravimetric method (ASSOCIATION..., 1990), after 0, 15, 30, 60, and 90 days of storage, and it was performed at the Grains and Byproducts Laboratory at Embrapa Rice and Beans.

The analyses of lipase activity (LA) and hydrolytic rancidity (HR) were performed only for the control and toasted samples (STB and WTB) at $0,30,60$, and 90 days of storage. This decision was made because the authors had no access to the industrial processes' details (such as temperature, moisture, time, concentration, etc. used for extrusion or parboiling), which were not disclosed, making it difficult a more critical and precise interpretation of the results if there were differences in these parameters. With regard to the DPB sample, these analyses would have little contribution to this study main objective since it is defatted.

LA determination was based on free fat acid production from the activity of that enzyme after its extraction and substrate addition, according to the methodology described by Goffman and Bergman (2003a). $200 \mathrm{mg}$ of sample and $2 \mathrm{~mL}$ of potassium phosphate buffer $(50 \mathrm{mM}), \mathrm{pH} 7.2$ were used for enzyme extraction with $1 \mathrm{~mL}$ of emulsion $(30 \mathrm{mg}$ of olive oil with $30 \mathrm{mg}$ of Tween 20 per $\mathrm{mL}$ of deionized water). After incubation $\left(35^{\circ} \mathrm{C} / 18\right.$ hours), isooctane addition, and reaction with the color reagent indicator $\left(3 \% \mathrm{v} \mathrm{v}^{-1}\right.$ of pyridine solution in $5 \% \mathrm{p} \mathrm{v}^{-1}$ of cupric acetate solution), an aliquot of the isooctane cupric acetate phase was read at $715 \mathrm{~nm}$ in a 700 plus Femto spectrophotometer. The results were expressed according to the free fatty acid content in milligrams of caprylic acid (C8:0) by $100 \mathrm{mg}$ of rice bran based on the standard curve of the caprylic acid (KWON; RHEE, 1986). The analyses were performed in quadruplicate.

Hydrolytic rancidity was determined in $100 \mathrm{mg}$ of bran and $3 \mathrm{~mL}$ of isooctane, according to the methodology described by Goffman and Bergman (2003a), shaking the suspension using a Shaker Incubating model 4500 for 3 minutes at $180 \mathrm{rpm}$. After the reaction with the color reagent indicator $\left(3 \% \mathrm{v} \mathrm{v}^{-1}\right.$ of pyridine solution in $5 \% \mathrm{p} \mathrm{v}^{-1}$ of cupric acetate solution), an aliquot of the

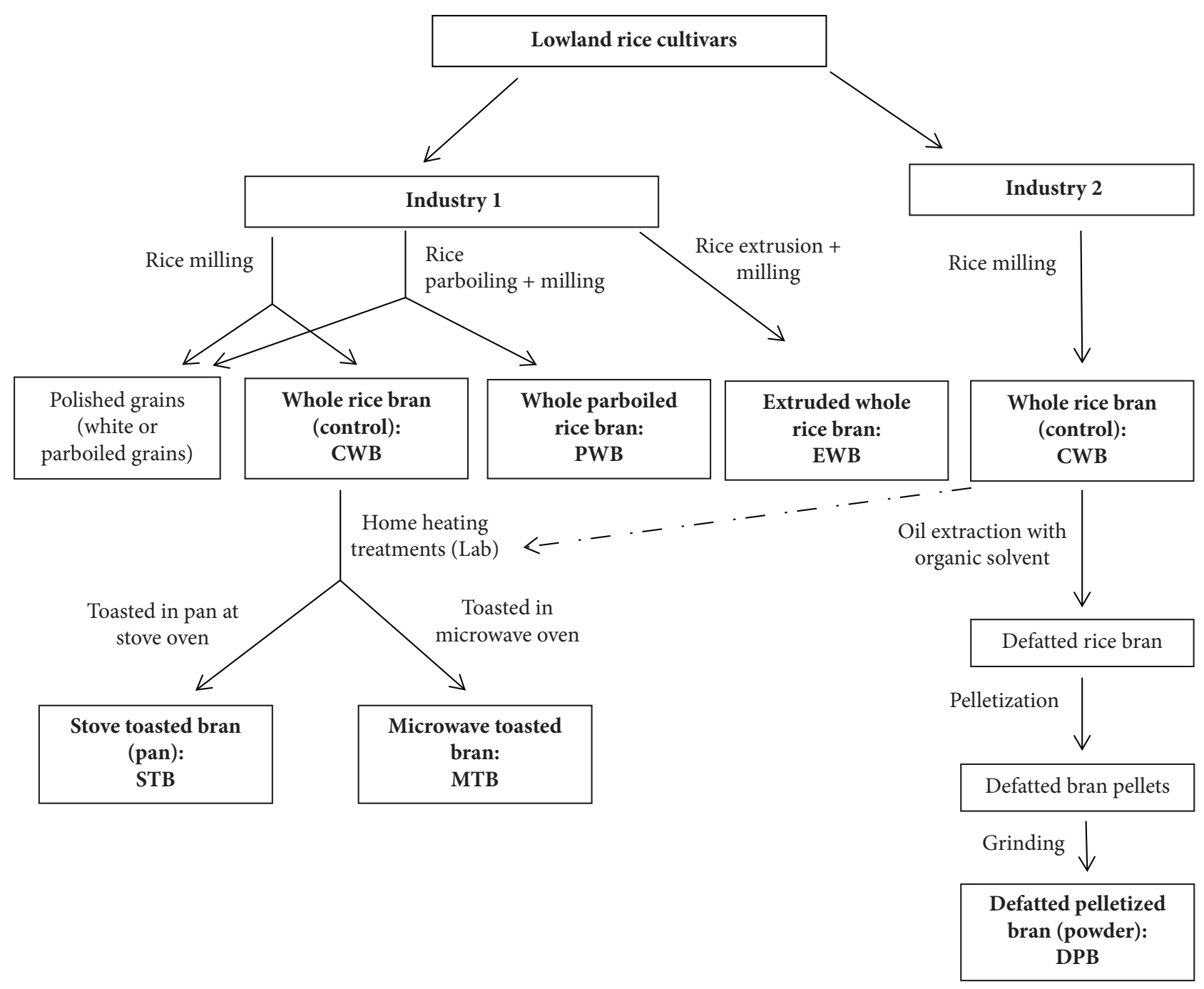

Figure 1. Scheme of rice bran collection and preparation for storage and analyses. 
isooctane phase was drawn for absorbance reading at $715 \mathrm{~nm}$ in a 700 Plus Femto spectrophotometer, calibrated with isooctane aliquot in cupric acid. HR was expressed according to the free fatty acid content, in milligrams of caprylic acid by $100 \mathrm{mg}$ of rice bran, based on the caprylic acid standard curve built according to Kwon and Rhee (1986). These analyses were done in triplicate.

\subsection{Microbiological analyses}

Assessment of microbiological quality was performed quantifying fungi and mold and yeast contents, at the Phytopathology Laboratory at Embrapa Rice and Beans, using the PDA medium (Potato, Dextrose Agar) acidified with tartaric acid (10\%) and pour plate method. For bacteria, plate standard counting PCA medium was used with the addition of pentachloronitrobenzene $\left(1.0 \mathrm{~g} \cdot \mathrm{mL}^{-1}\right)$. After sample inoculation, the Petri dishes were incubated at $25^{\circ} \mathrm{C}$ for 72 to 120 hours for fungi quantification and at $35^{\circ} \mathrm{C}$ for 48 hours for bacteria quantification. The results were expressed in colony forming units per grams of sample (UFC. $\mathrm{g}^{-1}$ ), according to Silva, Junqueira and Silveira (2001). All samples were evaluated at 0 , $15,30,60$, and 90 days of storage.

\subsection{Statistical analyses}

The experiment was arranged in a Completely Randomized Design with three repetitions and six treatments (CWB, PWB, EWB, DPB, MTB, and STB). The data were submitted to analysis of variance (ANOVA) and means compared by the Tukey test at $5 \%$ significance (STATISTICAL..., 2002).

\section{Results and discussion}

The moisture contents of all samples are shown in Table 2. Samples STB and EWB had the lowest moisture content for all storage periods, except for PWB at 60 day-storage, which showed a slightly lower moisture content than that of STB and higher than that of EWB.

It was visually observed that samples with the lowest moisture content had loose and soft particles, while samples with high moisture content had more agglutinated particles. However, it is not possible to say that the difference in texture observed resulted solely from the moisture content because sample DPB, with high moisture content, showed loose particles after grinding. The initial moisture content differences between the samples must be due to the different thermal processing treatments. DPB had the highest moisture content and kept it constant during storage; possibly due to its less drastic treatment and pellet shape, on which a small surface was exposed, and thus it became less subjected to moisture loss keeping the original appearance without color change. In general, thermal processes make samples drier, and a variation in their moisture content during storage until equilibrium is reached is expected. This variation in moisture content and equilibrium rate might be also a consequence of sample composition after treatment. The higher the temperature or sample heat contact during treatment, the drier the sample, and the faster and more expressive the moisture recovery during storage. These results show the importance of moisture control at the storage environment and
Table 1. Codification of rice bran samples according to their treatments.

\begin{tabular}{lll}
\hline $\begin{array}{c}\text { Sample } \\
\text { identification }\end{array}$ & \multicolumn{1}{c}{$\begin{array}{c}\text { Rice bran } \\
\text { treatment }\end{array}$} & \multicolumn{1}{c}{$\begin{array}{c}\text { Treatment } \\
\text { location }\end{array}$} \\
\hline CWB & Crude Whole Bran & $\begin{array}{l}\text { Non-treated (control) } \\
\text { (Industry 1) }\end{array}$ \\
PWB & Parboiled Whole Bran & Treated at Industry 1 \\
EWB & Extruded Whole Bran & Treated at Industry 1 \\
DPB & Defatted and Pelletized Bran & Treated at Industry 2 \\
MTB & Microwave Toasted Bran & Treated at the Lab \\
STB & Stove Toasted Bran, (pan) & Treated at the Lab \\
\hline
\end{tabular}

Table 2. Moisture content (\%) of rice bran samples during the 90 days of storage.

\begin{tabular}{ccrrrr}
\hline Bran & \multicolumn{5}{c}{ Time in storage (days) } \\
\cline { 2 - 6 } samples & 0 & \multicolumn{1}{c}{15} & \multicolumn{1}{c}{30} & \multicolumn{1}{c}{60} & \multicolumn{1}{c}{90} \\
\hline CWB & $9.66^{\mathrm{b}}$ & $9.26^{\mathrm{b}}$ & $10.20^{\mathrm{b}}$ & $10.13^{\mathrm{b}}$ & $8.73^{\mathrm{b}}$ \\
PWB & $8.06^{\mathrm{c}}$ & $8.26^{\mathrm{c}}$ & $9.13^{\mathrm{c}}$ & $7.93^{\mathrm{e}}$ & $7.53^{\mathrm{c}}$ \\
STB & $4.60^{\mathrm{e}}$ & $6.20^{\mathrm{f}}$ & $7.66^{\mathrm{e}}$ & $8.33^{\mathrm{d}}$ & $7.06^{\mathrm{d}}$ \\
DPB & $11.46^{\mathrm{a}}$ & $11.86^{\mathrm{a}}$ & $11.86^{\mathrm{a}}$ & $11.93^{\mathrm{a}}$ & $10.66^{\mathrm{a}}$ \\
MTB & $6.66^{\mathrm{d}}$ & $6.93^{\mathrm{d}}$ & $8.33^{\mathrm{d}}$ & $9.06^{\mathrm{c}}$ & $7.06^{\mathrm{d}}$ \\
EWB & $4.40^{\mathrm{f}}$ & $6.53^{\mathrm{e}}$ & $6.86^{\mathrm{f}}$ & $7.73^{\mathrm{f}}$ & $6.60^{\mathrm{e}}$ \\
\hline
\end{tabular}

${ }^{*}$ Means followed by the same letter in the rows do not statistically differ among them at $5 \%$ probability, by the Tukey test. Coefficient of Variance $(\mathrm{CV})=6.92 \%$. CWB - Crude Whole Bran; PWB - Parboiled Whole Bran; STB - Stove Toasted Bran; DPB - Defatted and Pelletized Bran MTB - Microwave Toasted Bran and EWB - Extruded Whole Bran.

Table 3. Mean colony forming of fungi (UFC. $\mathrm{g}^{-1}$ ) in samples of whole rice bran treated with different sources of heat.

\begin{tabular}{cccccc}
\hline \multirow{2}{*}{$\begin{array}{c}\text { Bran } \\
\text { samples }\end{array}$} & \multicolumn{5}{c}{ Time in storage (days) } \\
\cline { 2 - 6 } & 0 & 15 & 30 & 60 & 90 \\
\hline CWB & $4.2 \times 10^{4 \text { a* }}$ & $4.4 \times 10^{4 \mathrm{a}}$ & $3.5 \times 10^{3 \mathrm{a}}$ & $4.1 \times 10^{4 \mathrm{a}}$ & $4.1 \times 10^{4 \mathrm{a}}$ \\
PWB & $4.2 \times 10^{4 \mathrm{a}}$ & $4.0 \times 10^{4 \mathrm{a}}$ & $4.1 \times 10^{4 \mathrm{a}}$ & $4.0 \times 10^{4 \mathrm{a}}$ & $4.0 \times 10^{4 \mathrm{a}}$ \\
STB & nd & nd & nd & nd & nd \\
DPB & nd & nd & nd & nd & nd \\
MTB & nd & nd & nd & nd & nd \\
EWB & $2.0 \times 10^{4 \mathrm{~b}}$ & nd & nd & $2.2 \times 10^{4 \mathrm{~b}}$ & nd \\
\hline
\end{tabular}

${ }^{*}$ Means followed by the same letter in the rows do not statistically differ among them at $5 \%$ probability, by the Tukey test. Coefficient of Variance $(\mathrm{CV})=10.89 \%$. CWB - Crude Whole Bran; PWB - Parboiled Whole Bran; STB - Stove Toasted Bran; DPB - Defatted and Pelletized Bran MTB - Microwave Toasted Bran and EWB - Extruded Whole Bran; nd $=$ not detected.

Table 4. Standard bacteria counting in plates $\left(\mathrm{UFC} . \mathrm{g}^{-1}\right)$ in samples of rice bran treated with heat.

\begin{tabular}{|c|c|c|c|c|c|}
\hline \multirow{2}{*}{$\begin{array}{c}\text { Bran } \\
\text { samples }\end{array}$} & \multicolumn{5}{|c|}{ Time in storage (days) } \\
\hline & 0 & 15 & 30 & 60 & 90 \\
\hline CWB & $5.4 \times 10^{4}$ ax & $7.3 \times 10^{4 \mathrm{a}}$ & $6.4 \times 10^{4} \mathrm{a}$ & $6.3 \times 10^{4} \mathrm{a}$ & $6.0 \times 10^{4} \mathrm{a}$ \\
\hline PWB & $5.5 \times 10^{4}$ a & $5.2 \times 10^{4} \mathrm{a}$ & $2.7 \times 10^{4} \mathrm{~b}$ & $4.2 \times 10^{4 \mathrm{a}}$ & $5.9 \times 10^{4} \mathrm{a}$ \\
\hline STB & $6.2 \times 10^{4}$ a & $5.6 \times 10^{4} \mathrm{a}$ & $3.2 \times 10^{4}$ a & $1.5 \times 10^{4} \mathrm{~b}$ & $5.0 \times 10^{4}$ a \\
\hline DPB & $5.5 \times 10^{4}$ a & $6.1 \times 10^{4} \mathrm{a}$ & $4.8 \times 10^{4 \mathrm{a}}$ & $5.2 \times 10^{4}$ a & $6.2 \times 10^{4}$ a \\
\hline MTB & $5.8 \times 10^{4} \mathrm{a}$ & $3.1 \times 10^{4 \mathrm{~b}}$ & $2.4 \times 10^{4} \mathrm{~b}$ & $5.0 \times 10^{4} \mathrm{a}$ & $5.1 \times 10^{4} \mathrm{a}$ \\
\hline EWB & $6.2 \times 10^{4} \mathrm{a}$ & $5.2 \times 10^{4 \mathrm{a}}$ & $5.2 \times 10^{4} \mathrm{a}$ & $4.9 \times 10^{4 \mathrm{a}}$ & $5.2 \times 10^{4 \mathrm{a}}$ \\
\hline
\end{tabular}

${ }^{*}$ Means followed by the same letter in the rows do not statistically differ among them at $5 \%$ probability, by the Tukey test. Coefficient of Variance (CV) $=11.06 \%$. CWB - Crude Whole Bran; PWB - Parboiled Whole Bran; STB - Stove Toasted Bran; DPB - Defatted and Pelletized Bran MTB - Microwave Toasted Bran and EWB - Extruded Whole Bran. 
the use of appropriate packages to keep the desirable traits of the heat stabilized rice bran. It would be interesting to investigate longer storage period in order to check moisture stability.

Besides avoiding bacteria and fungi growth, bran stability was favored by low moisture content (Tables 3 and 4). The relationship between moisture content and fungi growth is in agreement with Vieira (1999), who states that moisture and temperature are critical factors for fungi growth and mycotoxins production. Presently, Brazilian legislation does not specifically refer to maximum moisture contents for rice bran, but the maximum allowed for flour in general is $13 \%$. In this study, the sample with the highest moisture content (11\%) remained within the legal limits established for flour.

According to the National Agency for Sanitary Surveillance (ANVISA), which establishes the microbial contamination limits of $3 \times 10^{3}$ UFC. $^{-1}$ for flour (BRASIL, 2001), the values found for total fungi counting (Table 3 ) in samples CWB, PWB, and EWB are above the acceptable standards.

The results found show the efficiency of the stabilizing treatments regarding total fungi counting for MTB samples (microwave treated), followed by STB (stove treated), and DPB samples (defatted and pelletized). These samples did not show any fungi growth in any of the storage times tested. However, the highest numbers for total fungi counting were found in PWB (parboiled) and CWB (control) samples, averaging $4 \times 10^{4}$ UFC. $^{-1}$ (Table 3 ). EWB sample (extruded) showed a different and unexpected behavior, with high contamination in the beginning of the storage period and recontamination from the sixtieth day on. Considering that all samples were manipulated and stored in the same way at the laboratory, one might suppose that the extruded sample was contaminated at the industry after heat treatment, and even though homogenization was performed, different fungi loads could have spread out the sample, which could be detected only for some of the storage periods. This makes one think that the control of microbial contamination of rice bran must occur in all steps of product manipulation up to consumption even though the thermal process may be considered efficient or safe.

The most efficient stabilization treatments concerning total fungi counting were: microwave oven toasting and heat applied to MTB sample, followed by stove toasting applied to STB and DPB samples. These samples did not show any fungi growth during the storage period; on the contrary, PWB and CWB samples (control) presented very high total fungi contents, averaging $4 \times 10^{4}$ (Table 3 ).

The absence of fungi in samples MTB, STB, and DPB could be attributed to their low moisture content associated with heat treatments since Aspergillus sp. is sensitive to high temperatures (JAY, 2000). MTB sample was exposed to microwave radiation, which could also have contributed to fungi elimination.

Fungi present in samples $\mathrm{CWB}, \mathrm{PWB}$, and EWB were identified as belonging to the genera Aspergillum, Penicillium and Fusarium. These genera are able to produce mycotoxins, especially aflatoxin, pathogenic to humans and animals; however, in this study, tests to verify the presence of that toxin were not conducted preventing any assertion concerning toxin production by those fungi. By comparison, cassava flour also presents mold of Aspergillum and Penicilium (CARDOSO; SILVA; CANO, 1995) suggesting that the same fungi mycrobiota would be typical of flours and related products.

It is important to mention that the samples used in this experiment did not follow specific sanitary standard procedure since they were intended for feed and organic fertilizers production. Therefore, rice bran produced for human consumption must follow specific sanitary and hygienic standards to achieve microbiological quality. The above observation calls the attention for the samples that were not thermally treated (CWB and $\mathrm{PWB}$ ) and for the sample treated at the industry 2 (EWB), which are not in accordance with the standards established by ANVISA (BRASIL, 2001); thus, the direct use of that raw material is not safe for human consumption since mycotoxins producing fungi were found in some samples.

For the standard bacteria counting in plate, no significant differences among the samples at the end of the storage period were observed (Table 4). ANVISA (BRASIL, 2001) does not specify tolerance limits for the counting test for rice bran, flours, and similar. However, Leitão et al. (1988) considered admissible maximum values between $10^{4}$ and $10^{6} \mathrm{UFC}^{-1} \mathrm{~g}^{-1}$ of aerobic mesophilic and facultative anaerobic bacteria counting based on general food legislation. According to their criterion, the good sanitary status of the tested samples after processing during the storage period are evidenced since the maximum bacteria counting did not exceed those limits in none of the samples for all storage times tested. In Brazil, there is no legislation concerning limits of tolerance for total fungi and standard bacteria counting in plates in rice bran for human consumption; therefore, the parameters here considered were those established by the Resolution RDC No 12 of January 2, 2001, from ANVISA, which establishes fungi and bacteria limits for food in general, including flour and bran. According to that resolution, all rice bran tested, except for the control (CWB) and PWB (parboiled), were free of fungi or had fungi contents compatible with Brazilian legislation (BRASIL, 2001).

The results on Tables 3 and 4 show a low microbiological activity, determined through the studied parameters, which could be attributed to two main factors: low contamination level during processing, handling, and storage; and unfavorable conditions for microorganisms' development, except for EWB sample.

Regarding the microbiological test, rice bran showed satisfactory results, within the standards established by the actual legislation for flour; they were considered appropriated regarding hygienic and sanitary quality, except for total fungi in samples CWB, PWB, and EWB. These results are very important because they demonstrate that the tests performed were effective in eliminating or keeping microorganisms within acceptable limits for further use in new food products or in human nutrition. However, it is important to call one's attention to the need for establishing tolerance limits for rice bran microbial load for human consumption to assure microbiological quality since there is no specific legislation for 
(a)

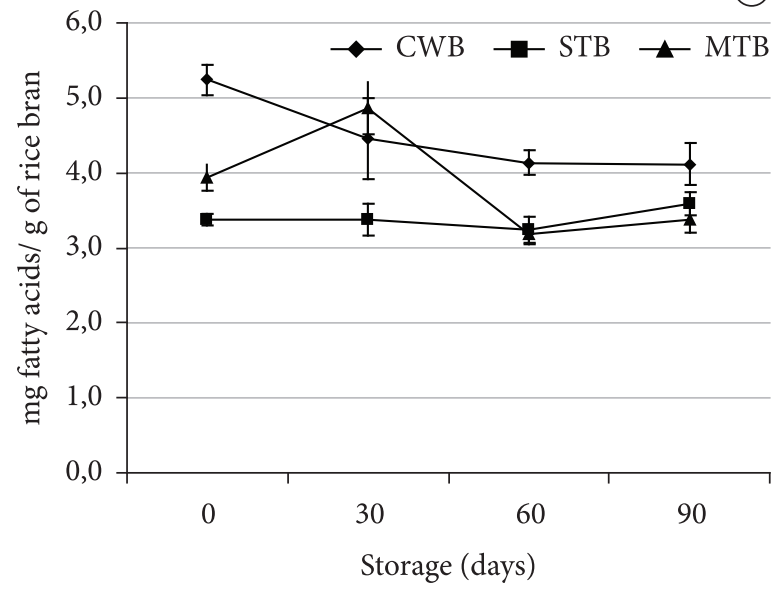

(b)

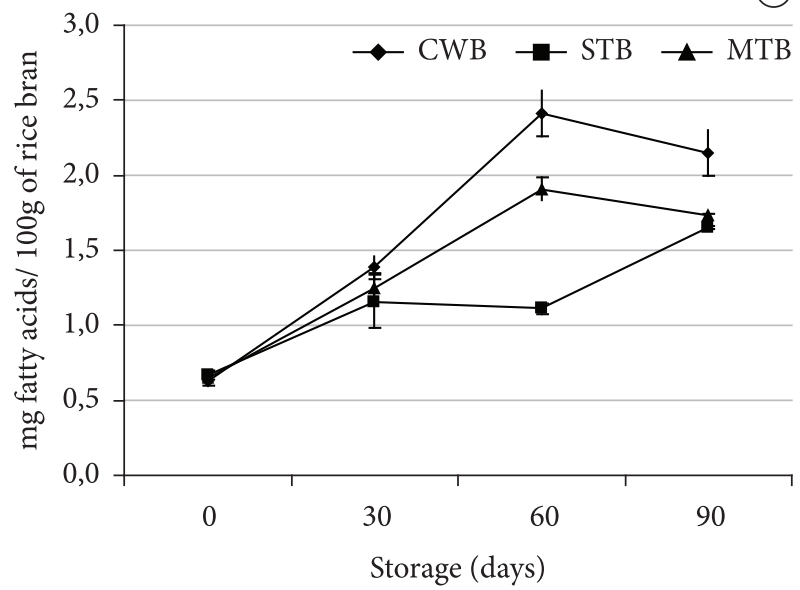

Figure 2. Lipase activity (a) and hydrolytic rancidity (b). Of rice bran samples during storage. Values are means of four (a) or three (b) replicates \pm standard deviation. Coefficient of Variance $(\mathrm{CV})=5.99 \%$ (a) and $18.92 \%$ (b) CWB - Crude Whole Bran; STB - Stove Toasted Bran; MTB - Microwave Toasted Bran.

this product, and a potential Brazilian food industry application might become a close reality.

The LA and HR results are illustrated in Figures 2a, b, respectively. According to Figure 2a, the control sample showed high LA in the beginning of the storage period with a slight reduction and stabilization of the activity after the thirtieth day, differing statistically $(p<0.05)$ from the others. That characteristic could be related to microbiological contamination since that sample had high fungi and bacteria contamination during storage. The stove treated sample (STB) showed the least LA results, which might be related to its lowest moisture content since the hydrolytic chemical reactions of the lipids are related to water content catalyzed by increases in temperature (ZAMBIAZI, 1997 apud by PESTANA et al., 2009). It differed statistically $(p<0.05$ ?) from the others indicating the efficacy of that treatment in controlling enzyme activity, and, consequently preventing bran rancidity. These results are compatible with those obtained by Goffman and Bergman (2003b) when studying no treated whole bran.

The microwave treatment seems to have slightly inhibited lipase activity and hydrolytic rancidity if compared to stove roasting; however, it is still more effective regarding the control of those parameters related to the non-treated bran, which is important for the preservation of some sensory and nutritional characteristics associated to oil degradation.

However, HR was less controlled by that process when one compares its profile with that of the other samples (Figure $2 b$ ). Ramezanzadeh et al. (1999) stored microwave oven heated-rice bran $(850 \mathrm{~W} / 3$ minutes.) for 16 weeks at room temperature, under $4-5{ }^{\circ} \mathrm{C}$ after packing it with different packaging, and compared its hydrolytic rancidity with that of the the raw bran (control). The authors observed that the control samples showed a rapidly increase of about 22 or 10 times in the hydrolytic rancidity over the period at room temperature or refrigerated conditions, respectively. The packaging had a small influence on the results. On the other hand, the microwave-heated samples presented low increase in the total fatty acid concentration (around 2.5 times) during storage at $25^{\circ} \mathrm{C}$, while no significant change was detected under $4-5^{\circ} \mathrm{C}$. They concluded that hydrolytic rancidity could be prevented by microwave heating, especially when the rice bran was stored under refrigeration.

Rice bran HR increased with storage time (Figure 2b), as expected, according to Goffman and Bergman (2003b), but that increase was statistically $(p<0.05)$ higher in whole bran samples and in those treated in microwave oven. Rancidity was statistically low $(p<0.05)$ in the stove treated samples indicating that home treatment partially inhibits rancidity during 60 days of storage. In general, comparing these results with those in the classification suggested by Goffman and Bergman (2003b) for hydrolytic rancidity versus oil content, the equivalent fatty acid (C8:0) values found are below $2.0 \mathrm{mg} / 100 \mathrm{mg}$ of bran or below $20.0 \mathrm{mg} \cdot \mathrm{g}^{-1}$ of bran, and are therefore considered low values. Fatty acids released at the beginning of the experiment did not differ statistically among the samples.

\section{Conclusions}

Whole bran samples roasted using a conventional stove and those treated in a microwave oven presented the lowest moisture content and adequate appearance for use in food up to the end of the storage period ( 90 days) suggesting that these heat treatments seem to be effective in keeping rice bran stability for longer periods.

Whole rice bran treatments in microwave oven and conventional stove were effective in eliminating or lowering total fungi, but the same cannot be said for bacterial load.

Regarding stability (rancidity and lipase activity control), the stove roasting treatment showed to be the most adequate; however, further studies are necessary to confirm these results. 


\section{Acknowledgements}

The authors are grateful to the industries Agroindustrial Urbano Ltda and Irgovel Indústria Riograndense de Óleos Vegetais Ltda. for the rice bran donation and to Embrapa Rice and Beans, Mara Pedrochi, Michela Okada technicians, Luciene Camarano and Roselene Chaves, for the text review and statistical analysis help.

\section{References}

ABDUL-HAMID, A.; LUAN, Y. S. Functional properties of dietary fibre prepared from defatted rice bran. Food Chemistry, v. 68, n. 1, p. 15-19, 2000. http://dx.doi.org/10.1016/S0308-8146(99)00145-4

ABOISSA ÓLEOS VEGETAIS. Farelo e óleo de arroz. Disponível em: <http://www.aboissa.com.br/produtos/view/438/Farelo_de_ arroz/>. Acesso em: 24 abr. 2012.

ASSOCIATION OF OFFICIAL ANALYTICAL CHEMISTS - AOAC. Official methods of analysis. Arlington: AOAC, 1990.

BASSINELLO, P. Z. Farelo de arroz, um alimento saudável. Brasil, 2004. Boletim Pecuário. Disponível em: <http://www.boletimpecuario. com.br/artigos/showartigo.php?arquivo=artigo936.txt\&tudo=sim $>$. Acesso em: 18 out. 2005.

BRANDÃO, C. Aproveitamento de folhas, sementes e outros - Multimistura. Multimistura, 2009. Disponível em: $<$ http:// solar8.multiply.com/links/item/107>. Acesso em: 23 dez. 2010.

BRASIL. Ministério da Saúde. Secretaria de Vigilância Sanitária. Resolução - RDC no 12, de 2 de janeiro de 2001. Aprova o Regulamento técnico sobre padrões microbiológicos para alimentos. Diário Oficial da República Federativa do Brasil, Brasília, DF, jan. 2001. Disponível em: <http://www.anvisa.gov.br/legis/ resol/12_01rdc.htm>. Acesso em: 13 ago 2006.

CARDOSO, M. W.; SILVA, G. G.; CANO, V. Análise de alimentos. Rio de Janeiro: Merck, 1995.

CARVALHO, C. W. P. Uso de farelo de arroz na produção de biscoitos tipo amanteigado. 1995. $114 \mathrm{f}$. Dissertação (Mestrado em Ciência e Tecnologia de Alimentos)-Universidade Federal de Viçosa, Viçosa, 1995.

CARVALHO, J. L. V.; BASSINELLO, P. Z. Aproveitamento Industrial. In: SANTOS, A. B.; STONE, L. F.; VIEIRA, N. R. A. (Orgs.). A cultura do arroz no Brasil: A cultura do arroz no Brasil. 2. ed. Santo Antônio de Goiás: EMBRAPA, 2006. p. 1007-1041.

CONTE, A. J. Valor nutritivo do farelo de arroz integral em rações para frangos de corte, suplementado com fitase e xilanase. 2000. 164 f. Tese (Doutorado em Ciência da Nutrição)Universidade Federal de Lavras, Lavras, 2000.

CROWLEY, L.; HALLIDAY, J. Rice bran approved as meat enhancer. FoodNavigator.com, 2008. Disponível em: < http://www. foodnavigator-usa.com/Financial-Industry/Rice-bran-approvedas-meat-enhancer>. Acesso em: 29 set. 2009.

DORS, G. C. et al. Distribution of pesticides in rice grain and rice bran. Journal of the Brazilian Chemical Society, v. 22, p. 19211930, 2011. http://dx.doi.org/10.1590/S0103-50532011001000013

DORS, G. C.; BIERHALS, V. S.; BADIALE-FURLONG, E. Parboiled rice: chemical composition and the occurrence of mycotoxins. Ciência e Tecnologia de Alimentos, v. 31, n. 1, p. 172-177, 2011. http://dx.doi.org/10.1590/S0101-20612011000100025

DOUAUD, C. NutraCea taking rice bran to big food players. FoodNavigator.com, 2007. Disponível em: <http://www.
nutraingredients-usa.com/Industry/NutraCea-taking-rice-branto-big-food-players $>$. Acesso em: 29 set. 2009.

GLUSHENKOVA, A. I. et al. Lipids of rice bran. Chemistry of Natural Compounds, v. 34, n. 3, p. 275-277, 1998. http://dx.doi.org/10.1007/ BF02282401

GOFFMAN, F. D.; BERGMAN, C. Relationship between hydrolytica rancidity, oil concentration, and esterase activity in rice bran. Cereal Chemistry, v. 80, n. 6, p. 689-692, 2003a. http://dx.doi.org/10.1094/ CCHEM.2003.80.6.689

GOFFMAN, F. D.; BERGMAN, C. Hydrolytic degradation of triacylglycerols and changes in fatty acid composition in rice bran during storage. Cereal Chemistry, v. 80, n. 4, p. 459-461, 2003 b. http://dx.doi.org/10.1094/CCHEM.2003.80.4.459

HOFFPAUER, D. W. New applications for whole rice bran. Cereal Foods World, v. 50, n. 4, p. 173-174, 2005.

JAY, J. M. Microbiologia de alimentos. 6. ed. Porto Alegre: Artmed, 2000.

KAHLON, T. S. Rice bran production, composition, functionality and food applications, physiological benefits. In: CHO, S. S. (Ed.). Fiber ingredients: food applications and health benefits. Boca Raton: CRC Press, 2009. http://dx.doi.org/10.1201/9781420043853-c14

KWON, D. Y.; RHEE, J. S. A simple and rapid colorimetric method for determination of free fatty acids for lipase assay. Journal American Oil Chemistry Society, v. 63, p. 89-92, 1986. http:// dx.doi.org/10.1007/BF02676129

LEITÃO, M. F. F. et al. Tratado de microbiologia: microbiologia de alimentos, sanitária e industrial. São Paulo: Manole, 1988. v. 1.

LLOYD, B. J.; SIEBENMORGEN, T. J.; BEERS, K. W. Effect of commercial processing on antioxidants in rice bran. Cereal Chemistry, v. 77, n. 5, p. 551-555, 2000.

LUH, B. S.; BARBER, S.; BARBER, C. B. Rice bran: chemistry and technology. In: LUH, B. S. Rice: utilization. 2nd ed. New York, 1991. p. 314-362.

MALEKIAN, F. et al. Lipase and lipoxygenase activity, functionality, and nutrient losses in rice bran during storage. Bulletin of the Louisiana Agricultural Experiment Station, n. 870, 2000.

MARSAIOLI JUNIOR, A.; ROCHA, C. R. Desenvolvimento da aplicação de microondas para produção de farelo de arroz estabilizado diretamente no grão em casca. In: CONGRESSO BRASILEIRO DA CADEIA PRODUTIVA DE ARROZ, 2.; REUNIÃO NACIONAL DE PESQUISA DE ARROZ, 8., 2006, Brasília. Anais... Brasília: Embrapa; Ministério da Agricultura, Pecuária e Abastecimento, 2006. Disponível em: <http://www.cnpaf. embrapa.br/publicacao/seriedocumentos/doc_196/trabalhos/CBCTRAB_104-1.pdf>. Acesso em: 31 set. 2009.

NOGARA, C. D. Farelo de arroz como suplemento alimentar: Avaliação da ação sobre insulin-like growth factor-I e oligoelementos. 1994. 82 f. Dissertação (Mestrado em Pediatria)Universidade Federal do Paraná, Curitiba, 1994.

RANDALL, J. M. et. al. Rice bran stabilization by extrusion cooking for extraction of edible oil. Journal of Food Science, v. 50, n. 2, p. 361-364, 1985. Abstract do banco de dados de Wiley InterScience. Disponível em: $<$ http://www3.interscience.wiley.com/ journal/119507576/abstract?CRETRY $=1 \&$ SRETRY $=0>$. Acesso em: 31 set. 2009.

PESTANA, V. R. et al. Efeito do armazenamento a baixa temperatura sobre a estabilidade do farelo de arroz. In: CONGRESSO DE INICIAÇÃO CIENTÍFICA - CIC, 18.; ENCONTRO DE PÓSGRADUAÇÃO - ENPOS, 11.; MOSTRA CIENTÍFICA, 1., 2009, Pelotas. Anais... Pelotas: UFPel, 2009. Disponível em: <http:// 
www.ufpel.tche.br/cic/2009/cd/pdf/CA/CA_00564.pdf>. Acesso em: 20 set. 2010.

RAMEZANZADEH, F. M. et al. Prevention of Hydrolytic Rancidity in Rice Bran during Storage. Journal of Agricultural and Food Chemistry, v. 47, n. 8, p. 3050-3052, 1999. http://dx.doi. org/10.1021/jf981335r

SAUNDERS, R. M. The properties of rice bran as a foodstuff. Cereal Foods World, Minneapolis, v. 35, n. 7, p. 632-636, 1990.

SLAVIN, J. L.; LAMPE, J. W. Health benefits of rice bran in human nutrition. Cereal Foods World, Minneapolis, v. 37, n. 10, p. 760763, 1992.

SILVA, M. A.; SANCHES, C.; AMANTE, E. R. Prevention of hydrolytic rancidity in rice bran. Journal of Food Engineering, v. 75, n. 4, p. 487-491, 2006. http://dx.doi.org/10.1016/j.jfoodeng.2005.03.066
SILVA, N.; JUNQUEIRA, V. C. A.; SILVEIRA, N. F. A. Manual de métodos de análise microbiológica de alimentos. São Paulo: Livraria Varela, 2001.

STATISTICAL ANALYSIS SYSTEM - SAS. Sistem for Windows 8.0 - Release 9.1.3. SAS Institute, 2002.

VIEIRA, A. P. Ocorrência de micotoxinas e características físicoquímica de farinhas comercializadas na zona sul do Rio Grande do sul. Revista da Sociedade Brasileira de Ciência e Tecnologia de Alimentos, v. 19, p. 221-225, 1999. http://dx.doi.org/10.1590/ S0101-20611999000200012

WEBER, L. R. H. Alimentação saudável e uso de multimistura: a experiência de Mato Leitão/RS. EMATER/RS-ASCAR, 2005. Disponível em: <http://www.emater.tche.br/site/area/frente5.php> Acesso em: 20 set. 2010. 